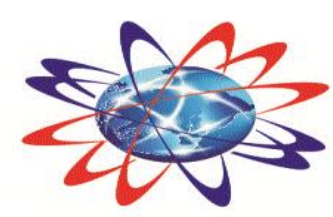

\title{
ICMSE 2014
}

INTERNATIONAL CONFERENCE ON MATHEMATICS, SCIENCE, AND EDUCATION

Faculty of Mathematics and Natural Sciences Semarang State University

Phone: +62248508112, 0818241519,081225069298

Website: www.icmse2014.com

\section{LOCAL SEISMIC HAZARD ASSESSMENT OF THE MATARAM CITY, INDONESIA BASED ON SINGLE STATION MICROTREMOR MEASUREMENT}

\author{
Syamsuddin $^{1,2 *}$, Kirbani Sri Probopuspito ${ }^{3}$, Junun Sartohadi ${ }^{4}$, Wiwit Suryanto ${ }^{3}$, M. Aryono Adhi ${ }^{1,5}$ \\ ${ }^{1}$ Ph.D. Student, Physics Department, Gadjah Mada University, Indonesia \\ ${ }^{2}$ Geophysical Laboratory, Physics Department, Mataram University, Indonesia \\ ${ }^{3}$ Geophysical Laboratory, Physics Department, Gadjah Mada University, Indonesia \\ ${ }^{4}$ Geography and Environmental Science Department, Gadjah Mada University, Indonesia \\ ${ }^{5}$ Physics Department, Semarang State University, IndonesiaSemarang State University Indonesia \\ *Email : syamsuddin@unram.ac.id
}

\begin{abstract}
Horizontal to vertical spectral ratio technique is used to assess the local seismic hazard through estimation of fundamental resonant frequency in Mataram city, Indonesia. In this study ambient noise measurements are carried out at 332 sites with the minimum duration of noise recording is about ten menit. Results of measurement indicate that the fundamental resonance frequency for Mataram range from 0.311 to $12,534 \mathrm{~Hz}$. The resonance frequency variation showed a heterogeneous lithological conditions of the area. The resonant frequency is low or high are the dominant period in the western city of Mataram, while the resonant frequency high or low dominant periods are in the eastern. This means that the western region is very prone to earthquakes. In addition, there is a good correlation was found between Geology of Mataram city and HVSR results obtained in this research.
\end{abstract}

Keywords: ambient noise, HVSR, Mataram, microtremor, Seismic Hazard

\section{INTRODUCTION}

It has been observed that the damage associated with the occurrence of earth tremors is the result, not only of magnitude of the earthquake of earth tremors and its epicentral distance, but also of local site effects which are essentially frequency dependent caused by topography and geology of the site. The reaction of the local geological conditions to the incoming seismic energy is known as the site response or local site effects (Fernandez et al., 2000). For seismic hazard assessment, the site effect is typically represented by resonance frequency and the associated ground motion amplification. Several methods exist such as array data analysis, horizontal to vertical ratio HVNSR, site to reference spectral ratio with a view to estimating such parameters. Out of these, use of ambient vibration records for determination of fundamental resonant frequency has recently gained worldwide acceptance. It is well known that soil deposits amplify ground motion. The amount of amplification depends on several factors including layer thickness, degree of compaction and age (Bonnefoy-Claudet et al., 2006). One of the many reasons for choosing ambient noise as widely accepted by several authors is that it allows the quick and reliable estimate of site characteristics of any type of area. Apart from being a cost effective measure, it reduces time compared to estimating site characteristics from earthquake which has always been a time consuming as well as expensive process so far as the maintenance of equipment and man power is concerned.

There are many instances of successful utilization of this $\mathrm{H} / \mathrm{V}$ ratio estimate towards studying fundamental frequency from ambient vibrations in urban environments (Duval et al., 2001; Lebrun et al., 2001; Guegen et al., 2000; Guillier et.al., 2007; , and GarciaJerez et al., 2007). The proximity of fundamental 
frequency of a site to the existing man-made structures causes damage of the later owing to resonance effects. Therefore, investigation of each site condition is an important step towards earthquake hazard mitigation.

Lombok Island Region of Lesser Sunda, Indonesia has been proclaimed as one of the most tectonically active region in the world. Two recent destructive earthquakes are one in 2004 and the other in 2013 had already ripped past through this region. One of the most striking features of Lombok Island Region, Indonesia that most of its cities and densely populated settlements are located in valley, sedimentary basins or hills etc. In this study, we try to shed light upon the site characteristics of Mataram City in terms of resonant frequency, site amplification etc using $\mathrm{H} / \mathrm{V}$ ratio methodology (Nakamura's 1989; as modified by Bard, 1999).

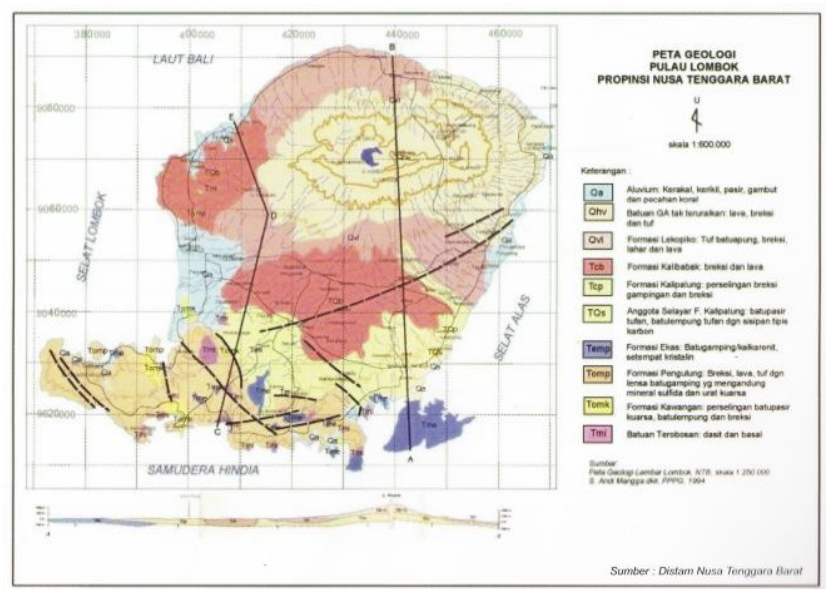

Fig. 1. Geological map of Lombok Island (Dinas Pertambangan NTB, 2010)

\section{Geology and Seimicity of the Study Area}

Lombok Island is one of a small island in the archipelago of Nusatenggara, Indonesia, tectonically is an area with seismic activity level is very high. This is due to its position adjacent to the zone of collision between the Eurasian and Indo-Australian Plate in the Indian Ocean where the Indo-Australian plate subduction under the Eurasian plate relative to the rate of about 71 $\mathrm{mm} / \mathrm{year}$. As a result of the collision the two plates, in the North of Lombok Island appear back arc thrust is active from Bali to Flores which is a shallow earthquake generator is very powerful and destructive. Based on data from BMKG, since 1973 to 2008 there have been more than 2000 times the incidence of earthquakes, and some of them are destructive earthquake (Fig. 1)

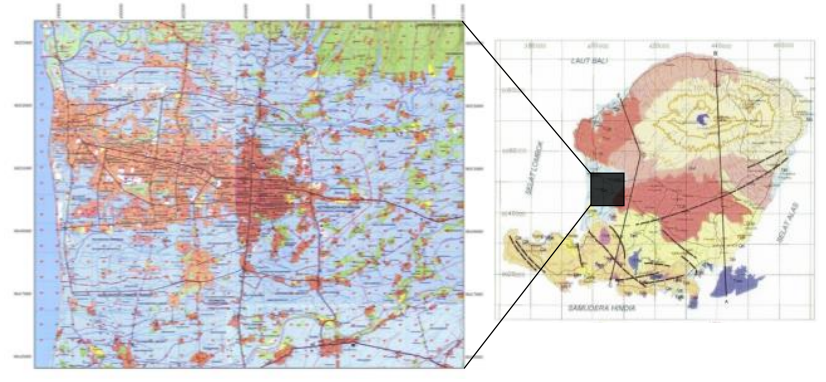

Fig. 2. Site location of survey

Two recent destructive earthquakes that have occurred around the Lombok Island such as West Lombok earthquake which occurred on January 24, 2004 with the epicenter at $8.260 \mathrm{~S}$ and $115.79 \mathrm{o} \mathrm{E}$ and depth of $33 \mathrm{~km}$ and $6.2 \mathrm{SR}$ scale ( IV MMI scale) with victims 30 people injured and 2241 houses were damaged and North Lombok earthquake which occurred on June 22, 2013 with the epicenter at $8.43 \mathrm{o} \mathrm{S}$ and $116.04 \mathrm{o} \mathrm{E}$ (about $14 \mathrm{~km}$ northwest of Lombok Island) and depth of $10 \mathrm{~km}$ and 5.4 SR scale (III-IV MMI scale) with victims 44 people injured and 5.370 houses were damaged (Dinas Pertambangan NTB, 2013).

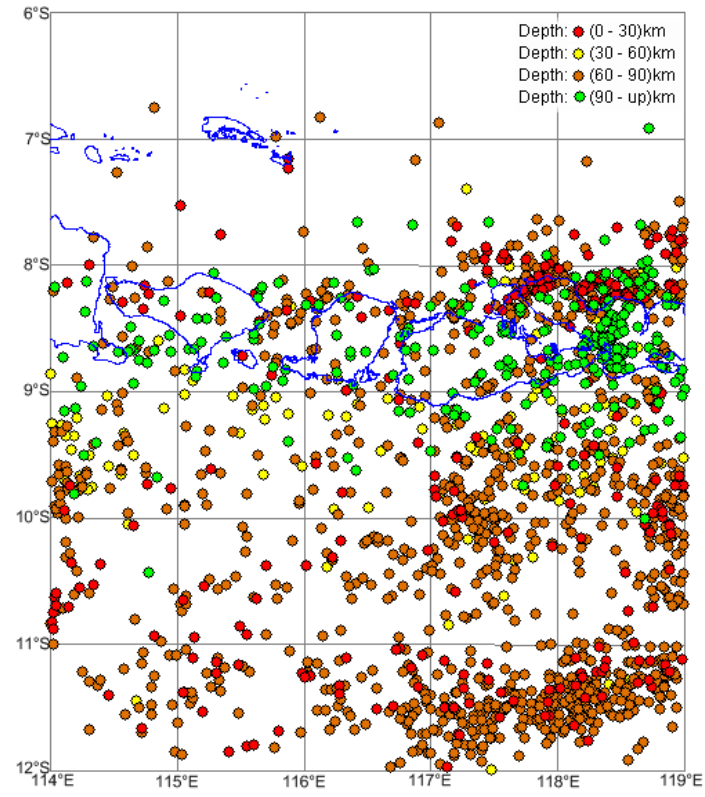

Fig. 3. Seismicity map of Lombok Island and surrounding region

On the other hand based lithology of Lombok Island composed of sediment that are relatively young with Tertiary to Quaternary age (Andi Mangga et.al., 1994). Rocks on the of Lombok island is dominated by volcanic rocks, consisting of volcanic breccia, lava and sandstone. In some places covered by sediment quarter relatively young that are unconsolidated. In the eastern part of the Lombok Island in the form of tertiary rocks are composed of breccias, lavas, tuffs, etc., in the western 
part of an alluvial area with a rock arrangement of alluvial or loose rock such as sand, gravel, and mud, in the northern part of the rock consists of Quaternary volcanic rocks precipitated from Rinjani volcano. The rocks are loose, especially around Rinjani volcanic. The sediment layer is quite thick, which cover nearly twothirds of the island of Lombok (Agustawijaya et.al., 2008; Agustawijaya \& Syamsuddin, 2012). This is according to a preliminary study conducted by the author based on USGS data showing that Vs30 soil layer in Mataram city and surrounding region has a value of shear wave velocity in the range of $200-300 \mathrm{~m} / \mathrm{s}$. According to the NEHRP standards that the value of D is considered very soft soil (stiff soil), which is potentially causing damage in case of an earthquake with a magnitude above 5 SR.

\section{Data and Methods}

a. Microtremor Measurements

In this study, microtremor measurements were done by using Data Logger Datamark LS-7000XT seismograph which dicouple dengan sensor portable microtremor equipment model L4C-3D (Mark Products). The velocity sensor used having a nominal natural frequency of $1 \mathrm{~Hz}$ and can measure three components of vibration, two horizontal and one vertical. The available frequency response range for the sensor is $1-100 \mathrm{~Hz}$. Digital recordings were made with a sampling rate of 100 samples per second. A global positioning system (GPS) was used for recording the coordinates of observation sites. The data from 227 sites were collected on August 2011 by Center for Geological Survey, Geological Agency, Indonesia and 105 sites were collected from 21 Juni to 10 Juli 2012 by Center for Vulcanology and Geology Mitigation Disaster, Geological Agency, Indonesia. The area was girdded with approximately $500 \mathrm{~m}$ grid spacing (Fig.5), and at each site ambient noise was recorded at a time window of $10-15$ minutes.

The seismometer was generally placed on a concrete or tar-sealed surface, but in cases where only grass or soft surface soil was available a movable concrete pad was used as a foundation to remove any resonance involving the seismometer and the ground. To ensure reliable noise recording, so we followed the guidelines proposed by Koller et al. (2004) in the framework of SESAME. Besides, quiet environment \& good weather condition had been our prime requisite for executing this data acquisition process. At each location field measurements sheet was filled in which described the time, date, operator name, coordinates etc of the location the onset and the duration of the measurement.

\section{b. Microtremor $\mathrm{H} / \mathrm{V}$ analysis}

Data were processed applying the horizontal-to vertical (H/V) spectral ratio (Nakamura, 1989) method, using the GEOPSY software package (www.geopsy.org). In pre-processing, all data convert to SAF format (SESAME ASCII Format). HVSR at each site computing with steps follow as (Duval et al. 2004): (1) Offset removal (baseline correction). Since similar sensors are used for all the three components, therefore no instrumental correction has been applied; (2) filter bandpass with frequency range from 1 to $20 \mathrm{~Hz}$; (3) Determination of stable time windows in the $20 \mathrm{~s}$ length and removing time windows contaminated by transients using an anti-trigger algoritms. This done to assure that only the coherent constituent of microtremors are included and the transient are discarded. This is done compare of short term average ('STA', the average level of signal amplitude over a short period of time, $1 \mathrm{~s}$ ) and long term average 'LTA' (the average level of signal over a much longer period of time, $30 \mathrm{~s}$ ). Only windows with threshold ratio STA/LTA from 0.3 to 2.5 we using for computing of $\mathrm{H} / \mathrm{V}$. (4) For each time window, a 5\% cosine taper function is applied on both sides of the window signal of the Vertical (V), North-South (NS) and East-West (EW) components; (5) The Fourier spectra were calculated for each time windows of the three components to obtain the three spectral amplitudes using the Fast Fourier Transform (FFT) and smoothed with using Konno-Ohmachi filter with constant bandwidth of $b=40$ (Konno \& Ohmachi, 1998). (6) Finally, the Fourier amplitude ratio of the two horizontal Fourier spectra and one vertical Fourier spectrum were obtained using Equation (1):

$$
r(f)=\frac{\sqrt{S_{N S}(f) \times S_{E W}(f)}}{S_{Z}(f)}
$$

Where $r(f)$ is the horizontal to vertical $(H / V)$ spectrum ratio, SNS(f), SEW(f) and SZ(f) are the Fourier amplitude spectra in the NS, EW and Vertical directions, respectively.

After obtaining the H/V spectra for the selected segments of the signal, the average of the spectra were obtained as the H/V spectrum for a particular site. The same procedure was repeated at all locations. The peak of the $\mathrm{H} / \mathrm{V}$ spectrum plot shows the predominant frequency of the site (f0) and the amplification factor (A0). Additionally, calculation of standard deviation for each point was done. 


\section{RESULTS AND DISCUSSIONS}

The main results obtained in this work refer mainly to the resonance frequencies (f0) of the sitesedimentary geology (site-soil columns) and the corresponding relative site-amplification factor (A0) derived from the amplitude of spectral ratios values.

Fig 4 portrays the map of resonant frequencies for Mataram City. We divide the resonance frequency into five classes. In the figure it is shown that the resonance frequency range in Mataram City is from $0.311 \mathrm{~Hz}$ to $12,534 \mathrm{~Hz}$ with a regular distribution pattern. Low resonance frequencies dominate, especially in the area of the western part of the city of Mataram which is associated with a low frequency thick sediment layer, this corresponds to Mataram city lithology sediment consisting of sand with a thickness of more than 30 meters. While the resonance frequency is located in the central part of the city of Mataram and high resonance frequency is in the eastern part of the city of Mataram. This means that based on the pattern of distribution of the resonance frequency region of the western city of Mataram is a region highly vulnerable to the threat of the earthquake disaster.

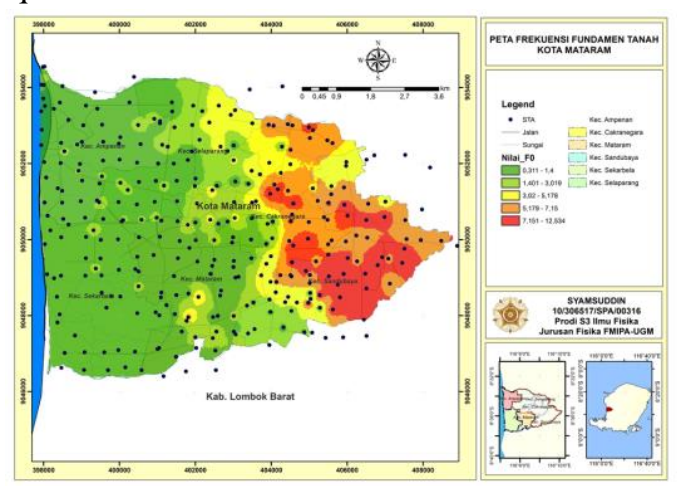

Fig. 4. Map of the resonance frequency (f0) for Mataram city

Fig. 5 is a map of the amplification factor in the city of Mataram which shows that values of the amplification factor range from 1 to 21 with an irregular pattern. Low amplification factor is in the central part of the city of Mataram and the amplification factor is medium to high there on the eastern and western part of the city of Mataram.

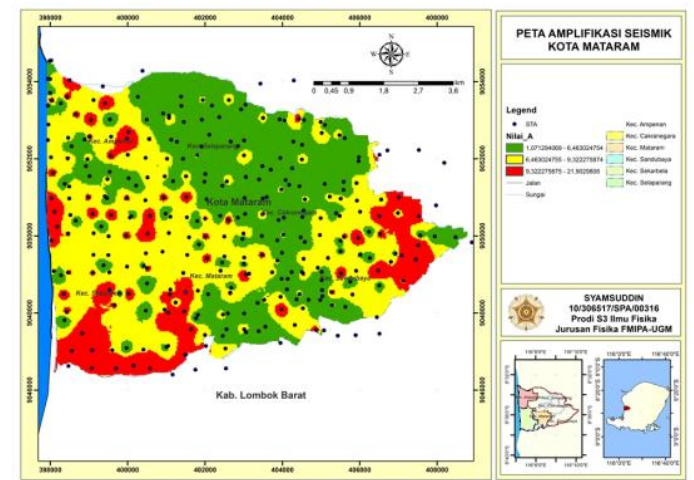

Fig. 5. Map of the amplification factor (A0) for Mataram city

Seismic vulnerability index of Mataram City we divide to be five classes. From Figure 6 it appears that the pattern of low seismic vulnerability distributed in the eastern city of Mataram, while moderate to high seismic vulnerability distributed in the western city of Mataram. Although the irregular distribution pattern, but there is a tendency of high seismic vulnerability in the western region. This is in accordance with the conditions of lithology mataram city where the western part is dominated by sand with a thickness of more than 30 meters.

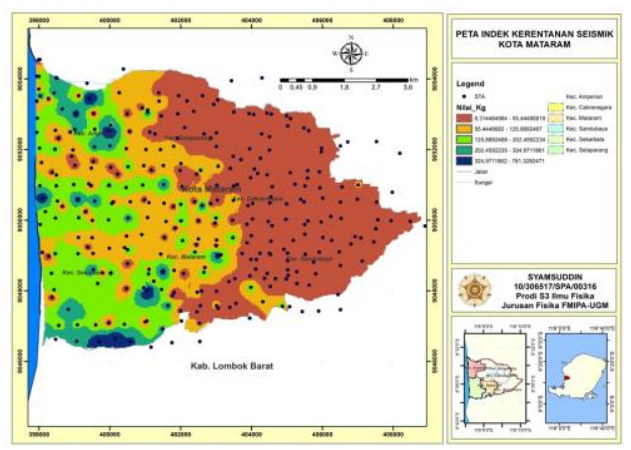

Fig. 6. Map of the seismic vulnerability index (K0) for Mataram city

\section{CONCLUSION}

The conclusions from this study are:

Ambient or background ground vibrations recorded on a portable seismograph and processed using the Nakamura method sometimes enables the potential resonance at a site to be evaluated.

The value of the Nakamura technique is that data on site response can be quickly gathered in the field, and analyzed to economically assess the resonant characteristics of a large number of sites.

The fundamental resonance frequency for Mataram city is found within the range of 0.311 to $12.534 \mathrm{~Hz}$. Low frequency or high dominant period is 
generally located in the western part of the city of Mataram and high frequency or low dominant periods are in the eastern part. Similarly, seismic vulnerability index has the same tendency, but the amplification factor has an irregular pattern.

In general, the western city of Mataram has high seismic vulnerability compared to the eastern region.

\section{ACKNOWLEDGMENT}

We would like to thank colleagues Asdani et.al. from the Center for Geological Survey and Dr. Nurhayati et.al. from the Center for Volcanology and Geological Disaster Mitigation for their permission to use and publish the data microtremor in Mataram. We also thank Mr. Israfil who have assisted in the data processing with ArGIS.

\section{REFERENCES}

Agustawijaya, D. S. (2006). Aspek-aspek Geologi Teknik dan Kegempaan dalam Analisis Resiko Gempabumi (in Indonesian), Orasi Ilmiah dalam rangka Dies Natalis Universitas Mataram ke 44, 2 Oktober 2006.

Agustawijaya, D.S. dan Syamsuddin, 2012. The Development of Hazard Risk Analysis Methods: A Case Study in Lombok Island, Dinamika Teknik Sipil, 12 (2), pp.146-150.

Andi Mangga, S., Atmawinata, S., Hermanto, B., dan Amin, T.C. (1994). Peta Geologi Lembar Lombok, Nusa Tenggara (in Indonesian), Direktorat Jendeal Geologi dan Sumberdaya Mineral, Departemen Pertambangan dan Energi.

Bard, P.Y. (1999). Microtremor measurements: a tool for site affects estimation? Proc. 2nd International Symp. on Effect of Surface Geology on Seismic Motion. Yokohama, Japan, 1251-1279.

Bonnefoy-Claudet, S., Cornou, C., Bard, P.Y., Cotton, F., Moczo, P., Kristek, J. and Fah, D (2006). H/V ratio: a tool for site effects evaluation. Results from 1 D noise simulations. Geophys. Jour. Int., v.167, pp.827-837.

Duval, A. M., Vidal .J.-P.Meneroud, Singer, A., Santis, F. De., Ramos, C., Romero G., Rodriguez, R., Pernia, A., Reyes, N. and Griman (2001). Site effect determination with micro tremors. Pure Appl. Geophys., v.158, pp.2513-2523.
Fernandez, L.M. and Brandt M.B.C. (2000). The reference spectral noise ratio method to evaluate the seismic response of a site, Soil Dynamics and Earthquake Engineering, v.20, pp381-388.

Guillier, B., Chatelain, J., Claudet S. B. and Haghshenas E. (2007). Use of ambient noise: From Spectral amplitude variability to H/V Stability. Jour. Earth. Eng., v.11, pp. 925-942.

Garcia-Jerez, A., Navarro, M., Alcala F. J., Luzon, F., Perez Ruiz, J.A., Enomoto T., Vidal, F. and Ocana, E. (2007). Shallow velocity structure using joint inversion of array and $\mathrm{h} / \mathrm{v}$ Spectral ratio of ambient noise: The case of Mula Town (SE of Spain). Soil Dynamic and Earthquake Engineering, v.27, pp.907-919.

Gueguen, P., Chatelain J.-L., Gullier, B. and Yepes, H. (2000). An indication of the soil topmost layer response in Quito (Ecuador) using noise $\mathrm{H} / \mathrm{V}$ spectral ratio. Soil Dynamics and Earthquake Engineering, v.19, pp.127-133.

Konno, K. and T. Ohmachi (1998). Ground motion characteristics estimated from spectral ratio between horizontal and vertical components of microtremor. Bull. Seism. Soc. Am., v.88 (1998) 228-241.

Koller, M., Chatelain, J.-L., Gullier, B., Duval, A.M., Atkan, K., Lacave, C., Bard, P.Y., and the SESAME participants (2004) Paper 3132, Practical user guideline and software for the implementation of the $\mathrm{h} / \mathrm{v}$ ratio technique on ambient vibrations : measuring the conditions, processing method and results interpretation, in 13th World Conference on Earthquake Engineering, Vancouver, B.C., Canada 1-6 August 2004.

Lebrun, B., Hatzfeld, D and Bard, P.Y. (2001) A site effect study in urban area: experimental results in Grenoble (France). Pure and Appl. Geophys., v.158, pp.2543-2557.

Lermo, J.E., and Chavez-Garcia, F.J. (1994) Are micortremors useful in site response evaluation? Bull. Seism. Soc. Am., v.84, no.1, pp.350-364.

Nakamura, Y., 1989. A method for dynamic characteristics estimation of subsurface using microtremor on the ground surface, Q.R. Rail. Tech. Res. Inst., 30, 25-30. 